\title{
The Niger Delta Oil Rich Region: The Paradox of Fascination and Horror
}

\author{
Usang, Eteng Eloma, Ph.D \\ Centre for General Studies, Crutech, Calabar \\ eloma01@yahoo.com. \\ Ikpeme, Nya John
}

Centre for General Studies, Cross River State University of Technology (CRUTECH), Calabar

Email:mfonsan@yahoo.com, Phone; 07064645100

\section{Doi:10.5901/ajis.2015.v4n1p117}

\begin{abstract}
Mankind is threatened by global environmental changes occasioned by man sporadic attempt to alter the design of nature. Man as the master of the earth and space is busy competing against himself in a dark lonely universe where the earth is the only oasis of life. In the Niger Delta region of Nigeria, we witness massive human starvation and poverty, extinctions of plants and animal species and dwindling biodiversity, caused by oil spillage and sweeping biotic destruction, global warming triggered and exacerbated by carbon dioxide, emission from the burning of fossil fuels, depletion of ozone layer by lethal chemical and concomitant bombardment of the earth by cancer causing extra-terrestrial ultra-violent radiation, pollution of air, water, land and life. Man quest to position himself on earth has resulted to the unsustainable discharges of waste gases into the atmosphere and large numbers of species extinctions throughout the world are but two of the most obvious indicators of the increasingly deleterious impact of human kind on the global biosphere. This paper focuses on the relationship between the exploitation of oil in the region and the devastation caused by the exploitation in the environment. It also true to establish how, the fascination of oil presence has resulted to horror and environmental degradation in the region.
\end{abstract}

\section{Introduction}

Citizens of the Niger Delta regions are threatened daily by global environmental changes because of the sporadic exploitation of God-given resources of the region. Man as the master of earth and space is busy competing against himself in a deliberate attempt to take authority, subdue and dominate the gift of nature in the environment of the region. God having created the Niger Delta region of Nigeria with abundant mineral deposits, he then became interested in whom to handover these good things of nature he has created to and finally decided to create the people of the Niger Delta. Being that God is good, the Niger Delta people he created were also good and so were all His creations. God then gave the people authority to subdue the region and harness its resources to their maximum benefit.

Being that God has satisfaction with all that he created, he gave this part of the universe graciously to the good people of the Niger Delta region comprising Bayelsa, Rivers, Edo, Delta, Akwa Ibom, Cross River States., Imo abia and Ondo States. Out of the minority of the inhabitance of the region, this God-given gift of nature (oil) was mortgaged entirely to the government of Nigeria, with the hope that government will reciprocate accordingly by providing social amenities and security to life and properties.

Today, the story in the region is pathetic as it has become more difficult for women to fetch ordinary clean drinking water from their streams and rivers or even fish in them. The people suffered undue impoverishment and dissatisfaction ranging from poor environmental sanitation, poor living condition, unemployment, unimproved farm yield, bad roads, poor healthcare delivery, ramshackle, and squalid housing conditions etc. Adeyemi Wilson (1991), Ekewe (1981), and Nwankwo (1981) maintained that the "sad experiences suffered by the people is caused by the impact of hydro-carbon exploitation which often end up in discharges into the environment. Drilling fluids and mud cuttings which are hazardous contain contaminants such as salts and soluble trace elements (e.g. zinc, lead, copper, calcium, nickel, arsenic, hydrosulphide) as well as toxic metals which are harmful to the community, man and the environment as a whole".

The effective exploitation of oil or valuable non-renewable natural resources is associated with increased social unrest and youth restiveness in the region. This high level of marginalization and neglect by the government has resulted to militancy, taken to hostages and kidnapping of expatriate workers, destruction of oil pipes and the likes. 


\section{Area of Study}

The Niger Delta region has a population of 27 million, covering an area of 70,000 square kilometers, with 5,000 communities, 50 ethnic groups and 250 dialects. The region is not only rich in oil and gas, but also well endowed with other natural resources like water, timber and other forest resources, wild life and sharp sand. It is the third largest wet lands in the world after the Amazon basin in Latin America with various species of aquatic organism and Trussville in Pennsylvania.

There are nine states in Niger Delta namely Rivers, Bayelsa and Delta constituting the core and original states through which the River Niger drains into the Atlantic Ocean and the others which include Akwa Ibom, Edo, and Cross River, Imo Abia and Ondo States. The significant feature of the Niger Delta is the state of underdevelopment not only by world standards but also in relation to many parts of Nigeria itself. The poverty of this region being the main source of the country's wealth is the paradox that posses one of the key challenges to our emerging democracy. Stakeholders who seek the evolution of democratic and stable governance in Nigeria must see the resolution of the Niger Delta paradox as a key building block.

Paradoxically, the Niger Delta was recognized as a region for special development initiative and attention in the independence constitutions of 1960. The-independence constitutions also recognized a special right of the region to oil and gas resources ownership. Thus, $50 \%$ of royalty deriving from oil and gas exploitation was paid to the oil producing regions or states. Sule (1991) the hazards of oil exploration from Oloibiri (1956-2007) have changed the structure of the region from stagnation of decay. Over the years, the oil rich Niger Delta region has been the backbone of Nigeria's economy and will remain so for years to come because oil exports account for over $90 \%$ of the country's foreign exchange earnings. Most of the oil and gas production that has earned Nigeria closed to $\$ 500$ billion in the past 4 years and half decades has been produced and exploited in the Niger Delta Ozumba (1999).

In spite of this, the scourge of poverty in the Niger Delta region is grim with the people lacking basic human needs and their environment willfully and constantly degraded by foreign oil companies and the Nigeria federation. With the ageing of most on-shore oil fields and the extinction of Oloibiri field, the oil producing communities have at various times suffered frequent oil spillages caused largely by lack of careful maintenance of the flow lines, persistent flaring of the gas for over 5 decades, and dumping of untreated toxic waste generated oil exploration and production into the creeks, rivers and land. As oil exploration and production moves off-shore, the Niger Delta is increasingly being polluted from land to sea.

The region is constantly threatened with huge loss of biodiversity. Massive pollution of surface and underground waters with increasing presence of lead and mercury. This has worsened the attendant health hazards, resulted in a dramatic increase of derived savannah in the world's third largest wetland, created rural land crisis, the specter of landlessness, food insecurity and constant extinction of aquatic life. This combined with other issues arising from poor governance and policies have partly shaped the structure of the underdevelopment of the Niger Delta region. Nigeria has made progress in strengthening its fragile democracy but faces social and economic challenges.

Table 1: Basic Comparative Indices between Nigeria and the Niger Delta Region

\begin{tabular}{|c|l|c|c|}
\hline S/N & HDI & NIGERIA & NIGER DELTA \\
\hline 1 & Population in Millions & 140 & 30 \\
\hline 2 & No. of persons per physician & 5,300 & 11,200 \\
\hline 3 & No of persons per hospital bed & 610 & 1,850 \\
\hline 4 & Infant mortality rate & 100 & 152 \\
\hline 5 & Life expectancy at birth (F) & 47 & 41 \\
\hline 6 & Life expectancy at birth (M) & 46 & 39 \\
\hline 7 & Literacy rate (total \%) & 71 & 43 \\
\hline 8 & Literacy rate (female \%) & 64 & 30 \\
\hline 9 & Literacy rate (male \%) & 76 & 56 \\
\hline 10 & Deforestation rate in \% & 20 & 25 \\
\hline 11 & No of threatened species & 230 & 15 \\
\hline
\end{tabular}

Source: UNDP Human Development Report on "The Niger Delta Commission as a Unifying Factor". Business Day, Monday, June 4, 2007 (Specific Focus on NDDC), p. 6.

Its human development indicators are among the world's lowest, as shown in table 1. Majority of Nigerians suffer from extreme poverty especially in the oil producing areas and the Niger Delta region. The table revealed the comparative indices between Nigerian and the Niger Delta. It shows very low development indices in the Niger Delta including health 
and life expectancy when compared to national average, still worse when compared to an acceptable international average. Average life expectancy index is basically low because of the impact of oil population and gas flaring in the region.

\section{Impact of Oil Exploitation in the Niger Delta Region}

Petroleum hydrocarbon and other substances discharged into the environment during hydrocarbon exploration and production have a range of impact on biota from mechanical and toxic to mutagenic effects. Almost all stages of hydrocarbon exploitation end up with discharges into the environment of hydrocarbon substances in various quantities.

However, the fate of oil in environment when spilled also depends on the amount spilled, spill location, the rate of spill and the nature of the oil e.g. fluid contained in oil are a mixture of a number of organic and inorganic compounds, including hydrocarbons. These fluids vary considerably in their appearance from gases to vicious black liquids.

Water based drilling muds may be released directly into the marine environment and discharges of drill cuttings. Such releases have potential impact to marine environment in different ways. Henderson, Grigson, Johnson and Roddle (1999) provide comprehensive review of the toxicity and drilling muds of various constituents. Neff (1987) noted that test for over 40 years on chronic and/or sub lethal effects of drilling muds and field observation on rates of dilution of drilling muds in water columns have been observed and it is concluded that water column organism will never exposed to drilling fluids long enough and at sufficiently high concentrations to elicit any acute or sub lethal response.

Olumide (2000:29-35) reports that volume of oil spilled in 1980 in Nigeria was on the high side especially during the Funiwa-5 disaster. Its effect on the environment includes noise pollution associated with drilling, refining operations and gas flaring. Adeyemi (1991), Ekewe (1981) and Nwankwo (1981) maintained that "oil spillage is responsible for the bulk of crude oil pollution in the world, it is the most invidious form of environmental depression. Drilling fluids and wind cutting are hazardous. They contain contaminants such as salts and soluble trace elements e.g. zinc, lead, copper, cadmium, nickel, arsenic, hydro-sulphide and toxic metals which are harmful to benthic community, man and the environment.

According to Manby (1999:59), a total of about 4,835 oil spill incidents involving 2,446,322 barrels of oil have been spilled between 1976-1996, of this quantity, about 1,820,410.5 barrels representing $77 \%$ were lost to the environment while the remaining $525,911.5$ barrels representing $25.6 \%$ of the total oil split was recovered.

Table II: Cr4ude Oil Production in Nigeria (1980-2001)

\begin{tabular}{|c|c|c|c|c|c|}
\hline S/N & Year & Oil Production Million Barrels & Revenue Million Naira & Spill incidence of Oil Spill & Volume of spill \\
\hline 1 & 1980 & 760.1 & 12,354 & 241 & 555,000 \\
2 & 1981 & 525.5 & 8,564 & 238 & 43,000 \\
3 & 1982 & 470.6 & 7,815 & 257 & 43,000 \\
4 & 1983 & 450.9 & 7,253 & 173 & 49,000 \\
5 & 1984 & 507.5 & 8,269 & 216 & 40,000 \\
6 & 1985 & 547.1 & 10,915 & 151 & 10,000 \\
7 & 1986 & 535.9 & 8,107 & 116 & 7,000 \\
8 & 1987 & 482.9 & 19,027 & 225 & 31,000 \\
9 & 1988 & 529.0 & 20,934 & 179 & 9,000 \\
10 & 1989 & 626.7 & 39,131 & 216 & $6,147.59$ \\
11 & 1990 & 660.6 & 55,216 & 119 & $15,264.11$ \\
12 & 1991 & 689.9 & 60,316 & 117 & $155,031.33$ \\
13 & 1992 & 711.3 & 115,392 & 184 & $27,161.54$ \\
14 & 1993 & 695.4 & 106,792 & 250 & $7,310.14$ \\
15 & 1994 & 696.2 & 160,192 & 270 & $32,259.70$ \\
16 & 1995 & 715.4 & 324,548 & 245 & $69,561.41$ \\
17 & 1996 & 681.9 & 416,190 & 264 & $43,841.35$ \\
18 & 1997 & 855.0 & 286,532 & 266 & $77,749.52$ \\
19 & 1998 & 806.4 & 500,000 & 113 & $59,338.68$ \\
20 & 1999 & 774.7 & $1,340,000$ & 260 & $28,013.72$ \\
21 & 2000 & 828.3 & $1,707,600$ & 340 & $71,788.58$ \\
22 & 2001 & 859.6 & 29.47 Trillion & 297 & $179,914.27$ \\
& & $21,613.9$ & 47.40 & $1,565,328.44$ \\
\hline
\end{tabular}

Source: Compiled from Annual Abstract of Statistics. Petroleum Inspectorate Division of NNPC, CBN Annual Report and Statement of Accounts and other Publications between 1980 and 2001. 
According to records compiled from various sources including annual abstracts statistics, the petroleum Inspectorate Division of NNPC. CBN statements of account and annual report between 1980 and 2001, a total of 12,946,628.15 incidents resulted in a 4,740 number of spill of barrel of oil into the environment comprising the air, water and land. The heaviest recorded spill so far occurred between 1979 and 1980 with a net volume of 739,628.15 barrels and 555.00 barrels respectively. The Funiwa blowout in 1980 (oil well blow out) was from Texaco's facility off Sangana about 5 miles offshore in Niger Delta generally referred to as Funiwa-5 Blowout and the spill continued until the well caught fire. The total number of barrels of oil produced between 1980-2001 was estimated at 21,613.9 million barrels, the total number of incidents amounted to 4,740 and this left the total number of barrels spilled between 1980-2001 at about 1,565,382.44 representing $7 \%$ of the total number of barrels produced from 1980-2001.

\section{Poverty and Underdevelopment of the Region}

Sunday punch of October 1, 2006 analyzed that: "Nigeria is the $13^{\text {th }}$ largest oil producer in the world with 32 billion barrels of oil reserved valued at $\$ 38.12$ billion per annum in July, 2006. Sufficient for the next 3 years, it is the $2^{\text {nd }}$ largest economy in Africa with annual GDP of $\$ 71$ billion, has no fewer than 75 million citizens out of a population of over 140 million people living in abject poverty (Daily Independent, Thursday, January 4, 2007 - Yinka Fayemi, p. E6), the table below shows the poverty incidence in Nigeria from 1980 - 2003.

Table III: Nigerian Population \& Poverty

\begin{tabular}{|c|c|c|c|}
\hline Year & Estimated population (M) & Poverty Incidence \% & Population in poverty (M) \\
\hline 1980 & 65 & 26.3 & 17.7 \\
1985 & 75 & 46.3 & 34.7 \\
1992 & 915 & 42.7 & 39.2 \\
1996 & 102.3 & 65.6 & 67.1 \\
2001 & 125 & 70.0 & 87.5 \\
2003 & 132 & 70.0 & 92.4 \\
\hline
\end{tabular}

Source: Draft National Policy on Poverty (2000) FOS Profile for Nigeria (1980-1996) in Sunday Punch, October 1, 2006.

According to the Fayemi "only India and China have larger number of poor people living within their borders. One of twenty Nigerians lives with HIVIAIDS. There are one million AIDS orphans in the country. Life expectancy for both men and women in Nigeria is 43 years. More than 7 in every 10 children, mostly girls, do not go to primary school. One child in every 10 children dies before reaching fifteenth birthday. Half of all Nigerians depended on agriculture for their living and this was the situation 100 years ago". The situation has not changed even with the heavy exploitation and production of oil in the region. Paucity and insecurity are linked in a vicious cycle. Breaking that cycle requires measures to promote human development, through access to reliable employment, education and social services. But it also requires measures to promote human security by offering protection from crime and political violence. Regardless of level of income, if people lack confidence in society's ability to protect them, they will have little incentive to invest in the future.

In Africa, according to Richardson (1993), the land is seen not in purely economic terms, but as belonging to a vast family of which many are dead, few are living, the countless members are unborn. According to him, African identities are based on the location of their ancestral spirits. This perhaps, explains the persistence of land-based problems and conflicts in Africa and the danger associated with its continuity. The environment therefore, has a clear link to peace and conflict in Africa.

\section{The Horror of a Fascinated Story in the Discovery of Oil and its Exploitation}

Environmental degradation is one of the challenges of human security in the world today. It is one of the greatest problems facing humanity as at now, ranging from Tsunami, fire disaster in France and other cities of the world, hurricane Katrina in the US and the flood in India, torrential rain in Britain and now earthquake in China. Haiti and Chile while Uganda landslide climate change is equally an important environmental issue disturbing the world.

The unsustainable discharges of waste gases into the atmosphere and large numbers of species extinctions throughout the world are the most indicators increasingly having a deleterious impact on humankind in the global biosphere. The ovation and great fascination that accompanied the minds of people especially people of Niger Delta for 
the discovery of oil, first at Oloibiri, and later the other Niger Delta regions of Nigeria soon died down because their expectation that the oil exploitation was to lead to economic growth and development was dashed. The imagination that the revenue from the oil was to be a solution to the diverse financial problems of the region as it was going to provide employment opportunities for their kindred, provide social amenities like pipe borne water, uninterrupted power supply, good roads and other social services has not been realized.

However, at the climax of high social expectation, the environment was speedily and highly degraded leading to;

i) Repressive government

ii) Social damages

iii) Human rights abuses,

iv) Poverty

v) Lack of regards on the cooperate social responsibilities towards the host communities;

vi) The threat on the livelihood of both oil-producing communities and the inhabitants of the area by the multinational companies operating in the region.

vii) Large scale pollution in making fishing and farming impossible and extremely difficult to the oil-producing communities and even making drinking water very scarce.

viii) The operation and presence of these companies had resulted to constant loss of properties of host communities, price inflation, prostitution and irresponsible fathering of children by expatriate oil workers.

ix) Complete marginalization and neglect of oil producing area leading to infrastructural decay, mass poverty, death, underdevelopment and repression.

\section{Reasons for Youth Restiveness in the Niger Delta Region of Nigeria}

The presence and exploitation of oil or valuable non-renewable natural resources is associated with increased social unrest and youth restiveness in the region. Based on the aforementioned organized protest and activism started in the affected communities. Their cry for justice continued though often ignored by both the multi-national corporations and the Nigeria government.

A notable author and environmental activist, Terisa Tumer commented on the issue noted that "the practice of the multinational corporations (MNC) are not and could not, be pursued in Western Europe of North America or anywhere". She further maintained that "environmental racism in the Niger Delta persists due to propaganda devised by corporate public relations, con-men, blinding oil consumers in the west from knowing or caring about the blood that is mixed with the oil they consume".

In Port Harcourt the presence of shell was felt since 1963 when she first started extraction of oil. The pipe lines were found to run through community settlements and in fragile environmental area. One such incident was massive fire burning from December to February damaging lots of things before it was put off. In Erema and Obaji communities where Total and EIF started the exploitation of oil since 1962, there had been regular gas flares which burned day and night and very close to residential areas. At Akala-Olu near Ahoada Italian Agip Company became a source of pollutant from gas flare with disastrous effect in health and buildings.

In Ogoni land prior to the arrival of Shell Company in 1958, the people were prosperous farmers/fishermen, but sooner, the area became the site of Shell facilities which devastated their farmland and environment. In Ogoni land, the resistance of environmental activists an Ogoni son, Ken Saro Wiwa was historic as he was executed with other activist for protesting against government and MNC. In Finima, the community was relocated for the construction of Liquified Natural Gas Plant (NLG). The community has now lost its ancestral home and her traditional source of livelihood. In Akassa, the community lost its traditional fishing business including their farmland due to the operations of Texaco.

At Kolo Creek, Shell's facilities started burning fire destroying local forests, streams and farmland around the Creek. Rumueke community hosted many oil companies like Total, EIF, Sheel and Agip because the area was the transport route for crude oil and gas to both Forcados and Bonny Island. The flare pit where gas it burnt uninterruptedly polluted the environment for years.

The death of Adaka Boro and a good number of youths either killed by government or put in detention further sparked the youths into provocative action resulting to pipe-line vandalization, kidnapping of expatriates, violence, militancy and wanton destruction of lives and properties. Insincerity in keeping terms of agreement by government, electoral thuggery, bad leadership, incessant use of the creek boys for political manipulation, violence and maneuvers of opponents created a wing of industrial reserve army who had seen that as the quickest means to wealth, recognition and status symbol. 
The Nation of Thursday, July 10, 2008 maintained that a group called the patriots said;

"We are deeply concerned that the crisis in the Niger Delta is escalating rather than abetting, this is apparently what has led to the government decision to declare war on the militants in response to the attack on the Bonga oil field".

Nwabueze (2008) in the same paper said;

"Who in the circumstances indicates desperation and is an acknowledgement of failure".

The Niger Delta militants are demanding for justice, calling for understanding dialogue, not war. He advised the government not to relent in its effort to engage the militants in dialogue aimed at finding negotiated settlement of their grievances without, of course, abandoning its duties to maintain law and order in the region. But war goes far beyond the legitimate requirements of law and order.

The Niger Delta militant, the group maintained is fighting for justice. War according to them is an appropriate response to the demand for justice. It only aggravates the injustice complained of and arouses the aggrieved citizens to a deeper feeling of disaffection and alienation. Nwabueze noted that in the region, you will see sheer waste of human resources, abuse of human rights and everything etc. The patriots said that the people of the region needed to be compensated.

Nwabueze went further -

There is a strong case that this people should be compensated being displaced from their homes, because of devastation, their natural occupation which is their means of livelihood is destroyed because of oil pollution. For this people have a genuine case. Justice is the foundation of every society. Without justice, we cannot have peace, we cannot have harmony. Federal government must find a way meeting the demands of the Niger Deltans. This should be done without abandoning its responsibility of law and order in the region.

\section{Conclusion}

With the discovery of commercial oil in Oloibiri in 1958 and subsequent exploitation of oil in similar other areas in the Niger Delta region in Nigeria, prompted the good people of the region to become fascinated by this God given gift of nature. The expectations were equally high, as they were told of the numerous benefits accruing to oil production, ranging from employment opportunities, provision of social amenities and exposure to international business etc. To confirm these postulations, Nigeria suddenly, became one of the top oil producing nations in the world and the petroleum industry. Gelb (1988) ascertain that crude oil soon became the mainstay of the country's economic policies, as oil accounted for $95 \%$ of the total export earnings of Nigeria. A fascinated growth rate of $3.7 \%$ of GDP of $\$ 72.632$ million dollar per capital income was recorded. Serious international attention was focused in the region with commercial activities build up occasioned by the arrival of different multinational corporations.

The different activities of these multinational oil companies caused the oil rich communities of the Niger Delta region to loss it ancestral homes and traditional sources of livelihood. Pollution and extreme environmental degradation including serious damages caused by gas flaring, explosions and oil spillages from broken and leaking pipe lines left unrepaired by oil companies, further, worsen the situations as the sea, lagoons, forests, fertile soils, mangrove swamps and fishing zones got grounded due to indiscriminate dumping of toxic waste and heavy metals already used by the oil companies at abandoned oil sites.

The situation as observed was compounded by lack of government investment in infrastructure including water, electricity and healthcare, housing and roads.

This ugly scenario created a reservoir of resistant restive groups today, known as militants and kidnappers whose targeted goal is to force recognition of the abandoned oil rich region. The horror created by these antecedents its better imagined than seen. Today, the Niger Delta oil rich region is a paradox of fascination and horror.

\section{References}

Adeyemi-Wilson, O. A. (1991). Environmental Issues in Oil Exploration and Production (Petro-Energy Upstream Operations).

Birtwell, I. K and McAlister, C. D. (2002). Hydrocarbons and their effects on Aquatic Organisms in Relation to Offshore Oil and Gas Exploration and Oil Well Blowout Scenarios in British Columbia. Canadian Tech. Rep. Fish Aquatic Science, 1391:61. CBN Annual Report and Statement of Account and Other Publications betweens 1980 - 2001 
Chindah, A. C., Braide, S. A. (2000). The impact of Oil Spills on the Ecology and Economy of the Niger Delta. Workshop on Sustainable remediation Development Technology held at the Instituted Pollution Studies, Rivers State University of Science \& Technology, Port Harcourt.

Cripps, S. J. \& Anabel, J. P. (2002). Environmental and Socio-economic Impact Assessment of Ekoreef. A Multiple Rigs-to-Reefs Development.

Draft National Policy on Poverty (2000). FOS Profile for Nigeria (1980-19960 in Sunday Punch, October 1, 2006.

Ekewe, E. (1981). The Faniwa-Oil Well Blowout. Paper Presentations at an International Seminar on the Petroleum Industry and the Nigerian Environment, 1981:64.

Gelb, A. H. (1988). Windfall Gains: Blessing or Curse? New York: Oxford University Press, 6.

Henderson, S. B., Grigson, S. J. W., Johnson, P \& Roddle, B. D. (1999). "Potential Impact of Production Chemicals on the Toxicity of Production Water Discharges from North Sea Oil Platforms". Marine Pollution Bulletin 38(12), 141-1151.

Khan, N. A. (1992). "Impacts of the Giant Intentional Oil Spill on Jubail, Saudi Arabia". Environmental Conservation 19(3), $259-261$.

Manby, Bronwen (1999:59). The Prince of Oil: Corporate Responsibility and Human Rights Violations in Nigeria's Oil Producing Communities. New York: Human Right Watch.

Neff, J. M. (1987). Biological Effects of Drilling Fluids, Drill Cuttings and Produced Waters In Boesch, D. F. and Rabalais N. N. Long Term Environmental Effects of Offshore Oil and Gas Development, 469-538. Elsevier Applies Science Publishers, London.

Nwabueze, B. O. (2008). Ideas and Facts in Constitution Making. Spectrum Books Limited, Sunshine House, Ibadan, Nigeria.

Nwankwo, J. N. (1981). "Problems of Environment and Control in the Nigerian Petroleum Industry and the Nigerian Environment". 1981: 102.

Olumide, A. J. (2000). Petroleum Production, the Environment and Nigerian Development. African Journal of Environmental Studies. Vol. 1, Nos. 1-2, 29-35.

Ozumba, C. I. (1999). Striking a Balance Between Oil Exploration and Protecting the Environment: The SPDC Experience. NAPE Bulletin. Vol. 14, No. 2, 130-135.

Richardson, W. J. \& Malme, C. I. (1993). Man-made Noise and Behavioural Responses in the Canadian Beaufort Sea. J Acoust. Soc. Am, 631-700.

Sule, R. O. (1982). "The Environmental Pollution consequences of Nigerian Oil Boom: The Socio-Economic Calamity of Oil Spillage in the Niger Delta Region". An International Journal of Physical, Biological, Social and Economic Geography and Applications in Environmental Planning and Ecology, Geo Journal, 1982-443.

Sule, R. O. (1991). "The Paradoxical Neglect of the Petroleum Producing Regions of Nigeria: A Revisitation". An International Journal of Physical, Biological, Social and Economic Geography and Applications in Environmental Planning and Ecology, Geo Journal, 413-416.

UNDP Human Development Report on the Niger Delta Development Commission as a Unifying Factor Business Day, Monday, June 4, 2007 (Specific Focus on NDDC), p. 6.

Wills, J. (2000). A survey of Offshore Oilfield Drilling Wastes and Disposal Techniques to reduce the Ecological Impact of Sea Dumping. http://www.offshore.environment.com/producedwater.

Worgu, S. O. (2001). Hydrocarbon Exploitation, Environmental Degradation and Poverty in Xthe Niger Delta Region of Nigeria. Sweden: Lund University Lumes Programmes. 
